\section{TERRITÓRIO, ESTADO E POLÍTICAS PÚBLICAS ESPACIAIS}

Marília Steinberger (Org)

Brasília: Ler Editora/CNPq, 2013

Ricardo Farret

Pesquisador Associado junto ao NEUR - Núcleo de Estudos Urbanos e Regionais da Universidade de Brasília

A obra Território, Estado e politicas públicas espaciais, organizada por Marília Steinberger, economista e professora do Departamento de Geografia da Universidade de Brasília, é fruto de uma linha de pesquisa que, com o apoio do CNPq, vem sendo desenvolvida desde meados dos anos 2000 e que tem no tema "políticas públicas espaciais" os seus pontos de partida e chegada. Trata-se do segundo produto dessa linha de investigação, dando continuidade ao livro publicado em 2006, Território, ambiente e politicas públicas espaciais.

A premissa central da linha de pesquisa parte da observação de que nem todas as políticas públicas nacionais - como a ambiental, a de ordenamento territorial, a regional, a urbana e a rural - podem ser adequadamente enquadradas na categorização corrente de políticas econômicas, sociais e setoriais. Nesse caso, segundo a organizadora, em comum, elas têm um DNA específico: uma fundamentação espacial, pois o que as une é o conceito de espaço geográfico, entendido, com base no pensamento de Milton Santos, não como mero receptáculo das açóes humanas, mas como uma entidade histórico-social que, ao ser produzido/modificado, transforma-se num 'território usado', isto é, abriga 'a materialidade mais a vida que a anima'. É a partir desse arcabouço que a linha de pesquisa que dá origem ao livro se aprofunda em análises comparativas entre os discursos das políticas públicas brasileiras, formuladas desde o final dos anos 1950.

De modo a identificar se e como o espaço/ território estava nelas presente, o livro se concentra nas políticas formuladas no horizonte temporal dos anos posteriores a 2002, quando, conforme os autores, começa de fato a retomada da produção de políticas públicas nacionais. Esse corte temporal não é gratuito.

De fato, no contexto do neoliberalismo, vigente até o início dos anos 2000, o pensamento dominante do estado mínimo levou o Estado Brasileiro, a despeito da edição de inúmeras medidas de política macroeconômica, à omissão em relação à formulação de um planejamento nacional e de políticas públicas, substituídas por uma gestão pontual e localista, via programas e projetos, inclusive ambientais, regionais, urbanos e rurais.

Como observa Antonio Carlos Galvão na sua Apresentação, depois de resistir à adoção dos princípios neoliberais nos anos 1980 e a ela sucumbir nos anos 1990, foi a partir de 2002 que o Brasil, ao retomar o campo das políticas sociais (centradas no combate à fome e à pobreza) e transformá-lo em eixo de estruturação de um novo projeto de desenvolvimento nacional - o qual, tendo como pano de fundo um quadro de profundas desigualdades sociais e espaciais -, fez com que o território emergisse como uma possibilidade e uma promessa para a reorganização do planejamento e das políticas públicas. Território, aqui entendido como 'território usado', na concepção conceitual de Milton Santos, como a expressão inequívoca da política, dos homens, mais que das coisas.

Numa tentativa de analisar o sentido e o direcionamento dessa retomada (do planejamento e) das políticas públicas, a partir de 2002, depois de identificar uma trajetória errática nessas políticas - com um misto de "participacionismo" e "ranço tecnocrático e autoritário"-, o livro prescreve a necessidade de discutir novos enfoques de políticas públicas, tais como o repensar a sua categorização/ tipologia e transferir as bases teórico-conceituais sobre o espaço geográfico e 'território usado' para a prática de sua produção. No livro, as respostas a tais questôes encontram amparo numa linha metodológica que divide as políticas (e "quase políticas") entre aquelas fortemente ancoradas no território e aquelas de outra natureza, embora com visíveis implicaçôes espaciais.

Com Prefácio e Apresentação altamente elucidativos no que concerne às imbricações do planejamento e da formulação das políticas públicas 
com as ideologias de desenvolvimento no mundo contemporâneo, o livro compóe-se de três partes. A primeira, Discussóes teóricas e metodológicas, com três capítulos, examina o atual sentido do Estado e sua relação com políticas públicas e território; a importância política da categoria 'território usado'; e os parâmetros analíticos adotados para o entendimento da relaçấo políticas públicasdiscursos. Para isso, o livro apoia-se em análises da atualidade capitalista, elaboradas por autores de peso, tais como Eric Hobsbawn, Jürgen Habermas, Boaventura de Sousa Santos, David Harvey e István Mészáros, visando a examinar o papel do Estado e dos espaços nacionais. Ao lado disso, a fim de relacionar essas ideias às especificidades brasileiras, é inserido nessa parte do livro o pensamento de importantes autores nacionais, como Celso Furtado, Helio Jaguaribe, Milton Santos, Carlos Lessa e Samuel Pinheiro Guimarães.

Nas partes restantes - a segunda, Políticas públicas espaciais, e a terceira, Politicas de relevante impacto espacial-territorial -, os autores do livro, a partir de uma criteriosa análise de documentos oficiais, realizam um trabalho de fôlego visando à identificação do real conteúdo das políticas públicas nacionais, por meio de três parâmetros que dão a necessária unicidade à análise: (i) o conteúdo formal da proposta; (ii) o 'jogo político' de fazer política e (iii) a abordagem espacial-territorial -este último considerado como o parâmetro-síntese das acepçóes, explícitas e implícitas, de espaço e território nos documentos analisados.

Nesse enfoque, enquanto a segunda parte, em cinco capítulos, vasculha as políticas ambiental, a de ordenamento territorial, a regional, a urbana e a rural, a terceira, também com cinco capítulos, disseca as políticas industrial, a de turismo, a de habitação, a de transportes e a de inclusão digital, totalizando dez políticas públicas específicas.

Finalmente, cabe destacar outros aspectos do livro que, sendo produzido de forma coletiva e na academia - mas náo exclusivamente para a academia -, reforçam a qualidade da obra. Em primeiro lugar, a autoria distribuída entre alunos e ex-alunos de Marília Steinberger, a organizadora da obra, denotando a verdadeira função do desenvolvimento de uma linha de pesquisa acadêmica; em segundo lugar, a total adesáo dos diversos artigos que compóem o livro ao seu marco teórico-metodológico. Foge, assim, do padrão, muitas vezes presente em obras dessa natureza, em que os artigos têm vida própria, no mais das vezes, uma coletânea de textos requentados, distanciados do foco proposto. Finalmente, quando, não raras vezes, é mais fácil publicar um livro que um artigo em revista científica de credibilidade, a obra inova ao criar um Conselho Editorial, ad hoc e independente, constituído por professores de diversas universidades, nenhum da Universidade de Brasília, o que legitima ainda mais a obra.

Concluindo, torna-se importante assinalar que, pela atualidade e relevância de sua temática, pela consistência teórico-metodológica de sua produção e pelo seu conteúdo final, não hesito em recomendar a leitura e a discussáo dessa obra aos segmentos da academia e aos formuladores de políticas públicas engajados na retomada da questáo espacial no planejamento brasileiro, em todas as suas escalas. 